\title{
PENGARUH PENDIDIKAN KESEHATAN DENGAN BERNYANYI LAGU CUCI TANGAN TERHADAP TINDAKAN MENCUCI TANGAN ANAK PRASEKOLAH
}

\author{
The Effect of Health Education by Singing Handwashing Songs to Hand Wash \\ Techniques
}

\author{
Dewa Gede Juliawan ${ }^{1}$, Ni Ketut Ayu Mirayanti ${ }^{2}$, Ni Ayu Parwati ${ }^{3}$ \\ ${ }^{1,3}$ Departemen Keperawatan Medikal Bedah, STIKES Wira Medika Bali, Denpasar, Bali, Indonesia \\ ${ }^{2}$ Departemen Keperawatan Komunitas, STIKES Wira Medika Bali, Denpasar, Bali, Indonesia \\ Korespondensi : dewa.juliawan1084@gmail.com
}

\begin{abstract}
ABSTRAK
Mencuci tangan merupakan salah satu tindakan sanitasi dengan cara membersihkan tangan dan jari-jemari yang bertujuan agar tangan menjadi bersih. Dampak dari kurang dilaksanakannya kebiasaan cuci tangan yang sering menyerang anak usia pra sekolah adalah diare, ISPA, cacingan dan demam tifoid. Informasi mengenai mencuci tangan dengan sabun ini perlu disosialisasikan melalui metode promosi kesehatan cuci tangan yang menarik untuk anak yakni metode bernyanyi. Melalui bernyanyi anak menjadi senang dan lebih mudah dalam memahami materi ajar yang disampaikan. Tujuan penelitian ini adalah mengetahui pengaruh pendidikan kesehatan dengan bernyanyi lagu cuci tangan terhadap tindakan mencuci tangan pada anak usia pra sekolah. Jenis penelitian pra eksperimental dengan menggunakan rancangan one-group pre-post test design. Jumlah sampel sebanyak 22 orang dengan purposive sampling. Pengumpulan data menggunakan lembar observasi. Hasil penelitian menunjukkan rata-rata tindakan mencuci tangan anak usia pra sekolah sebelum diberikan pendidikan kesehatan dengan bernyanyi lagu cuci tangan adalah 10,41, setelah diberikan pendidikan kesehatan dengan bernyanyi lagu cuci tangan adalah 16,36 . Hasil uji paired-t didapatkan nilai $\mathrm{p}=0,000$, artinya ada pengaruh pendidikan kesehatan dengan bernyanyi lagu cuci tangan terhadap tindakan mencuci tangan pada anak usia pra sekolah. Cara tepat untuk mengubah perilaku adalah dengan cara pendekatan edukatif, salah satu pendekatan edukatif yaitu bernyanyi. Institusi pendidikan diharapkan adanya jadwal khusus dalam memberikan pendidikan kesehatan.
\end{abstract}

Kata Kunci: pendidikan kesehatan, bernyanyi, mencuci tangan

\section{ABSTRACT}

Washing hand is one of sanitation actions by cleaning hands and fingers that is aimed in making hands clean. The impact of the lack in hand-washing practices that often affect preschool children is diarrhea, respiratory infection, intestinal worms and typhoid fever. Information about washing hand within soap needs to be socialized through an exciting handwashing promotion method for children,one of them is singing. Through singing, the childrenwill be happy and easier to understand the lesson. The purpose of this study is to know the effect of health education by singing handwashing songs to hand washing actions in preschool children. This pre experimental study using the one-group design pre-post test design.Total 22 people with Purposive sampling. Data was collected using observation sheet. The result show that the average hand washing action of pre-school children before being given health education by singing handwashing song was only 10.41, after being given health education by singing handwashing song is 16,36. Paired t test results show p-value $=0,000$, means there is the influence of health education by singing handwashing songs to washing hand on pre-school children. The right way to change behavior is by way of educative approach, one of the educative approach is singing. Educational institutions suggested to have a special schedule in providing health education.

Keywords: health education, singing, handwashing 
Dewa Gede Juliawan: Pengaruh Pendidikan Kesehatan Dengan Bernyanyi Lagu Cuci Tangan Terhadap Tindakan Mencuci Tangan Anak Prasekolah

\section{PENDAHULUAN}

Masa anak prasekolah adalah masa yang paling penting dalam proses pembentukan dan pengembangan kepribadian sehingga menjadi orang yang bertanggung jawab untuk diri sendiri maupun sosial masyarakat (Mulyadi, 2015). Anak prasekolah berada di usia golden age yaitu sekitar 4 hingga 6 tahun, pada masa ini anak-anak membutuhkan bahasa dan hubungan sosial yang lebih luas, mempelajari standar peran, memperoleh kontrol dan penguasaan diri, semakin menyadari sifat ketergantungan dan kemandirian serta mulai membentuk konsep diri (Wong, 2014). Anak pada fase ini, rasa ingin tahu dan minat bereksplorasi terhadap lingkungan semakin meningkat sehingga anak pra sekolah rentan menderita penyakit yang berhubungan dengan hygiene (Anugrah, 2014).

Cuci Tangan Pakai Sabun (CTPS) merupakan salah satu Perilaku Hidup Bersih dan Sehat (PHBS) yang telah menjadi perhatian dunia, hal ini karena masalah kurangnya praktek perilaku cuci tangan tidak hanya terjadi di negara-negara berkembang saja, tetapi ternyata di negaranegara maju kebanyakan masyarakatnya masih lupa untuk melakukan perilaku cuci tangan (Mukhtar, 2016). Rapat Umum Perserikatan Bangsa-Bangsa menetapkan Hari Cuci Tangan Pakai Sabun Sedunia (HCTPS) setiap tanggal 5 Mei.Fokus HCTPS pada anak pra sekolah sebagai "Agen Perubahan" dengan simbolisme bersatunya seluruh komponen keluarga, rumah dan masyarakat dalam merayakan komitmen untuk perubahan yang lebih baik dalam berperilaku sehat melalui CTPS (Depkes RI, 2013).

Data World Health Organization (WHO) tahun 2016 menunjukkan perilaku cuci tangan pakai sabun pada anak hanya 33,6\%. Data Profil Kesehatan tahun 2016, menunjukkan bahwa sekitar $17 \%$ anak usia sekolah melakukan CTPS dengan benar (Departemen Kesehatan Republik Indonesi, 2016). Hasil penelitian dari Ponidjan (2016) menyebutkan bahwa CTPS pada anak didapatkan perbandingan prevalensi kegiatan rutin CTPS anak disekolah 3,85\%, dirumah $1,85 \%$ dan keduanya $1,37 \%$.
Pramono (2016) juga menyebutkan sebanyak $76,8 \%$ usia sekolah belum benar dalam perilaku cuci tangan.

Dampak dari kurang dilaksanakannya kebiasaan cuci tangan yang sering menyerang anak usia prasekolah adalah penyakit seperti diare, ISPA (Infeksi Saluran Pernafasan Atas), cacingan dan demam tifoid. Hal ini disebabkan bibit penyakit akan lebih mudah masuk ke dalam tubuh apabila tangan dalam keadaan kotor (Anugrah, 2014). Berdasarkan hasil penelitian yang dilakukan oleh Rosyidah (2014) yang berjudul hubungan perilaku cuci tangan terhadapkejadian diare pada siswa di SekolahDasar Negeri Ciputat 02 diperoleh bahwa ada hubungan antara perilaku cuci tangan terhadap kejadian diare dengan nilai $\mathrm{p}$ value $=0.015$, sedangkan hasil penelitian yang dilakukan oleh Nisarosalinah (2017) yang berjudul hubungan perilaku cuci tangan dengan kejadian ISPA pada anak usia sekolah di SD kartika XII Akmil Magelang diperoleh bahwa ada hubungan perilaku cuci dengan kajadian ISPA pada anak usia sekolah di SD Kartika XII Akmil Magelang dengan $p$ $0,04<0,05$. Pendidikan kesehatan merupakan usaha atau kegiatan untuk membantu individu, kelompok atau masyarakat, khususnya anak prasekolah dalam meningkatkan kemampuan perilaku untuk mencapai kesehatan mereka secara optimal.

Materi yang akan disampaikan di dalam pendidikan kesehatan kepada individu, keluarga, kelompok dan masyarakat hendaknya disesuaikan dengan kebutuhan kesehatan, usia, budaya, jenis kelamin dan lain-lain. Sehingga materi yang disampaikan dapat dimengerti dan bermanfaat bagi sasaran. Begitu juga cara menyampaikan pendidikan kesehatan kepada anak, yaitu harus sesuai dengan usia dan perkembangan yang sedang ia tempuh, agar anak mampu menangkap materi dan mengikuti apa yang diajarkan kepada mereka, dilihat dari sasaran pemberian promosi kesehatan ini, yakni anak usia empat sampai enam tahun, maka media pembelajaran yang tepat adalah bermain sambil belajar interaktif di mana dapat melatih kreatifitas anak (Rasyid, 2014). 
Penelitian Ramadhan (2014) menunjukkan terdapat perbedaan metode ceramah dan bermain dalampenyuluhan kesehatan gigi dan mulut terhadappengetahuan siswa SDladang bambumedan tuntungan dimana penyuluhan kesehatan gigi dan mulut denganmetode bermain lebih memiliki nilai tambahdan lebih efektif digunakan pada anak-anaksekolah dasar. Penyuluhan kesehatan pada anak-anak lebih berhasil jika dilakukan dengan berpedoman pada proses belajar dan bermain. Oleh karena itu, metode bermain di anggap lebih efektif dibandingkan metode ceramah.

Dunia anak adalah bermain dan bernyanyi, sehingga ketika anak-anak berada di sekolah TK (Taman Kanak-kanak) kegiatan tidak lepas dari bermain dan bernyanyi dengan tujuan untuk mendidik dan mengembangkan ketrampilan anak.Salah satu metode promosi kesehatan cuci tangan yang menarik untuk anak yakni metode bernyanyi.Melalui bernyanyi anak menjadi senang dan lebih mudah dalam memahami materi ajar yang disampaikan (Lestari, 2012).Bernyanyi merupakan salah satu unsur yang menciptakan kegembiraan dan suasana riang. Pelatihan, pembiasaan dan pedidikan pada usia dini akan lebih efektif apabila digunakan media bernyanyi. Selain tidak terkesan menggurui, memerintah atau melarang dan mudah diingat (Wiflihani, 2012).

Metode bernyanyi adalah salah satu bentuk metode yang bisa menggontrol dan mengamati setiap dari perkembangan anak, seperti perkembangan verbal, pendengaran daya tangkap, motorik, peniruan dan lain sebagainya. Selain itu, nyanyian dapat membuat belajar menjadi lebih menyenangkan dan anak tidak cepat bosan, sehingga informasi akan mudah ditangkap (Rahmawati, 2014) .Metode bernyanyi adalah salah satu bentuk metode yang bisa menggontrol dan mengamati setiap dari perkembangan anak, seperti perkembangan verbalnya, pendengarannya daya tangkap, motorik dan peniruan. Metode bernyanyi memberikan cara belajar yang sangat menyenangkan bagi anak karena dilakukan seperti bermain. Selain itu, peragaan cuci tangan yang menyertai metode bernyanyi menyebabkan anak dapat secara langsung mempraktekkan secara tepat intervensi yang telah diberikan, sehingga materi yang disampaikan lebih mudah diterima oleh anak (Lestari, 2012).

Hasil penelitian yang dilakukan oleh Listyowati (2014), menunjukkan bahwa intervensi promosi kesehatan yang dilakukan terbukti dapat meningkatkan pengetahuan, sikap dan praktek siswa kelas 5 SDN Pengasinan IV Kota Bekasi mengenai cuci tangan pakai sabun ( $p=$ $0,000 \leq 0.05)$ sedangkan penelitian yang dilakukan oleh Rindafit (2015) menunjukkan bahwa terdapat efektifitas pendidikan kesehatan terhadap praktik cuci tangan pada anak prasekolah di PAUD Darunnajah Desa Tamansari Kecamatan Wuluhan Kabupaten Jember $(\mathrm{p}=0,000$ $\leq 0.05)$. Penelitian Pangesti (2015) menunjukkan terdapat pengaruh pada pemberian pendidikan kesehatan menggunakan metode storytelling dan permainan ular tangga terhadap tingkat pengetahuan mencuci tangan pakai sabun di TK Al-Hidayah Ajung Kabupaten Jember ( $p$ $=0,001 \leq 0.05$ ).

Hasil studi pendahuluan di tiga Sekolah Taman Kanak-Kanak di Kecamatan Denpasar Barat pada Bulan Maret 2018 yaitu yaitu TK Bakti 3 Denpasar dari 10 yang di observasi anak hanya 3 anak yang mampu melakukan tindakan cuci tangan dengan benar. TK Eka Dharma Kumara Denpasar dari 10 anak yang dilakukan observasi 6 anak sudah mampu melakukan teknik cuci tangan dengan benar, TK Bintang Besar Denpasar dari 10 anak yang dilakukan observasi sebanyak 8 anak sudah mampu melakukan tindakan cuci tangan dengan benar. Melalui wawancara dengan Kepala TK Bakti 3 Denpasar bahwa setiap tahunnya diare pada siswa terus meningkat.Kepala TK juga menyampaikan bahwa sudah memberikan pendidikan kesehatan tentang cuci tangan pada anak dengan metode ceramah dan demonstrasi, sudah ada fasilitas seperti tempat cuci tangan.Namun anak-anak belum melakukan cuci tangan dengan maksimal. Salah satu cara agar anak melakukan mencuci tangan yaitu dengan memberikan pendidikan kesehatan melalui metode bernyanyi agar anak mudah mengerti dan mampu mencuci 
Dewa Gede Juliawan: Pengaruh Pendidikan Kesehatan Dengan Bernyanyi Lagu Cuci Tangan Terhadap Tindakan Mencuci Tangan Anak Prasekolah

tangan dengan benar. Anak yang menderita diare di TK Bakti 3 Denpasar pada bulan Januari-Maret 2018 sebanyak 20 orang.

Berdasarkan latar belakang diatas, peneliti tertarik untuk meneliti tentang pengaruh pendidikan kesehatan dengan bernyanyi lagu cuci tangan terhadap tindakan mencuci tangan pada anak usia prasekolah di Sekolah Taman Kanak-Kanak Bakti 3 Denpasar.

\section{TUJUAN PENELITIAN}

Penelitian ini bertujuan untuk mengetahui pengaruh pendidikan kesehatan dengan bernyanyi lagu cuci tangan terhadap tindakan mencuci tangan pada anak usia prasekolah

\section{METODE PENELITIAN}

Desain

Pada penelitian ini menggunakan metode penelitian Pra Eksperimental yaitu percobaan berupa perlakuan atau intervensi terhadap suatu variabel, dari perlakuan tersebut diharapkan terjadi perubahan (Setiadi, 2015). Rancangan yang dilakukan dalam penelitian ini menggunakan one group pre test-post test design.

\section{Populasi dan Sampel}

Populasi penelitian ini adalah seluruh siswa Taman Kanak-Kanak Bakti 3 Denpasar. Jumlah sampel pada penelitian ini sebanyak 22 orang, tehnik sampling yang digunakan adalah purposive sampling.

\section{Tempat dan Waktu Penelitian}

Penelitian ini bertempat di Taman Kanak-Kanak Bakti 3 Denpasar. Waktu pengambilan data dilakukan selama 3 minggu.

\section{Instrumen dan Prosedur Pengukuran}

Instrumen yang digunakan dalam penelitian ini adalah lembar observasi yang memuat prosedur cuci tangan 6 langkah.

\section{Analisa Data}

Analisa data pada penelitian ini mengunakan uji paired-t dengan hasil uji normalitas data pre test didapatkan hasil $\mathrm{p}=$ $0,079>0.05$ dan data post test didapatkan hasil $\mathrm{p}=0,089>0.05$.

\section{HASIL PENELITIAN}

Berdasarkan penelitian yang dilakukan, didapatkan hasil sebagai berikut:

Tabel 1

Karakteristik Responden ( $\mathrm{n}=22)$

\begin{tabular}{|c|c|c|}
\hline $\begin{array}{c}\text { Jenis } \\
\text { Kelamin }\end{array}$ & Frekuensi & $\begin{array}{c}\text { Presenta } \\
\text { se }\end{array}$ \\
\hline Laki-laki & 8 & 36.4 \\
\hline Perempuan & 14 & 63.6 \\
\hline Total & 22 & 100.0 \\
\hline
\end{tabular}

Berdasarkan tabel 1 mayoritas responden berjenis kelamin perempuan sebagian besar yaitu 14 orang $(63,6 \%)$

Tabel 2

Pengaruh Pendidikan Kesehatan dengan Bernyanyi Lagu Cuci Tangan terhadap Tindakan Mencuci Tangan Anak Prasekolah

\begin{tabular}{lcccc}
\hline Variabel & Mean & $\begin{array}{c}\text { Beda } \\
\text { Mean }\end{array}$ & $\begin{array}{c}p \\
\text { value }\end{array}$ & $\begin{array}{c}\mathrm{t} \\
\text { hitu } \\
\text { ng }\end{array}$ \\
\hline $\begin{array}{l}\text { Pre Test } \\
\text { Tindakan }\end{array}$ & 10,41 & & & \\
$\begin{array}{l}\text { Mencuci } \\
\text { Tangan }\end{array}$ & & & & \\
\hline $\begin{array}{l}\text { Pos Test } \\
\text { Tindakan }\end{array}$ & 16,36 & 5,96 & 0,00 & $\begin{array}{c}12,04 \\
\text { Mencuci } \\
\text { Tangan }\end{array}$ \\
\hline
\end{tabular}

Berdasarkan tabel 2 di atas menunjukkan terjadi peningkatan rata-rata tindakan mencuci tangan anak usia prasekolah sebelum dan setelah diberikan pendidikan kesehatan dengan bernyanyi lagu cuci sebesar 5,96. Hasil uji dengan Paired $t$ Test diperoleh nilai $\mathrm{p}=0,000$ dan $\alpha<0,05$ artinya ada pengaruh pendidikan kesehatan dengan bernyanyi lagu cuci tangan terhadap tindakan mencuci tangan pada anak usia prasekolah di Sekolah Taman Kanak-Kanak Bakti 3 Denpasar.

\section{PEMBAHASAN}

Hasil penelitian menunjukan rata-rata tindakan mencuci tangan anak usia prasekolah sebelum diberikan pendidikan kesehatan dengan bernyanyi lagu cuci tangan adalah 10,41, nilai median 10 , skor 
minimum 8 dan maksimum 14. Menurut Fitriasari (2014) yang mengatakan tidakan mencuci tangan anak usia prasekolah dipengaruhi oleh pengetahuan yang dimiliki khususnya penggunaan air mengalir, penggunaan sabun serta langkah-langkah mencuci tangan. Anak kurang mampu menerapkan langkah-langkah mencuci tangan disamping disebabkan karena pengetahuan dapat juga disebabkan anak belum terpapar informasi tentang cara mencuci tangan baik dari orang tua, guru serta belum tersediasnya media informasi seperti poster ataupun gambar-gambar yang mengajarkan cara mencuci tangan. Hal ini sesuai dengan pendapat Purwanto (2012) dimana sumber informasi seperti media cetak, informasi dari teman, guru, keluarga, maupun tenaga kesehatan dapat mempengaruhi tindakan mencuci tangan pada anak.

Menurut Kushartanti (2012) tindakan anak mencuci tangan masih kurang dipengaruhi oleh kurangnya stimulus dari luar antara laian orang tua dan guru. Orang tua adalah tokoh panutan anak, maka diharapkan orang tua dapat ditiru, sehingga anak yang bebas bersekolahpun sudah mau dan mampu melakukan cuci tangan dengan benar melalui model yang ditiru dari orang tuanya. Guru merupakan individu yang sering dijumpai anak dalam lingkungan sekolah. Tugas guru sebagai pengajar dan pendidik yang salah satu diantaranya adalah mengajarkan praktek cuci tangan pakai sabun pada anak sekolah. Pendapat Kushartanti (2012) sejalan dengan pendapat Apriany (2012) yang mengatakan kebiasaan cuci tangan pada umumnya sudah diperkenalkan kepada anak-anak sejak kecil, tidak hanya oleh orang tua di rumah bahkan menjadi salah satu kegiatan rutin yang diajarkan para guru di Taman KanakKanak sampai dengan Sekolah Dasar.

Hasil penelitian ini sejalan dengan hasil penelitian sebelumnya yang dilakukan oleh Rindafit (2015) tentang efektifitas pendidikan kesehatan terhadap praktik cuci tangan pada anak prasekolah di PAUD Darunnajah Tamansari Wuluhan Jember. Hasil penelitian menunjukkan bahwa hampir seluruh responden tidak melakukan praktik cuci tangan dengan baik sebelum diberikan pendidikan kesehatan tentang cuci tangan yaitu sebanyak 26 responden (83,9\%). Penelitian Ilmi (2015) pengaruh pendidikan kesehatan dengan metode bernyanyi terhadap prilaku mencuci tangan anak prasekolah di TK RA Perwanida Krangkongan Tegalwangi Umbulsari Jember. Hasil penelitian didapatkan nilai rata-rata prilaku mencuci tangan sebelum diberikan pendidikan kesehatan dengan metode bernyanyi adalah 2,48 , nilai tersebut masuk dalam kategorinilai kurang.

Tindakan mencuci tangan anak usia prasekolah di Sekolah Taman Kanak-Kanak Bakti 3 Denpasar termasuk kategori kurang. Hal ini terjadi karena sesuai dengan keterangan dari kepala sekolah bahwa selama ini sudah memberikan pendidikan kesehatan tentang cuci tangan pada anak dengan metode ceramah dan demonstrasi akan tetapi belum dilakukan secara teratur serta saat pendidikan kesehatan dilakukan anak mudah bosan serta tertarik untuk mengikuti. Menurut peneliti keterampilan yang dilatih melalui praktik akan menjadi kebiasaan apa bila dilakukan secara berulang-ulang. Saat dilakukan observasi menunjukkan semua anak tidak melakukan tindakan menggosok dan memutar ujung jari-jari tangan kanan di telapak tangan kiri dan sebaliknya. Mayoritas responden tidak melakukan tindakan menggosok kedua telapak tangan dan sela-sela jari tangan, tindakan jari-jari sisi dalam kedua tangan saling mengunci dan menggosok ibu jari kiri berputar dalam genggaman tangan kanan dan dilakukan sebaliknya.

Peneliti berpendapat, tindakan mencuci tangan anak usia prasekolah selain dipengaruhi oleh faktor internal seperti pengetahuan dan sikap anak juga dapat dipengaruhi oleh faktor eksternal yaitu faktor lingkungan khususnya orang tua. Tindakan mencuci tangan anak usia prasekolah terbentuk melalui proses belajar, baik mencontoh maupun bimbingan orang tua. Faktor lingkungan keluarga khususnya orang tua, sangat besar peranannya dalam mengembangkan perilaku positif terhadap kesehatan melalui tindakan mencuci tangan, orang tua harus turut memperhatikan perilaku anak berkaitan dengan kesehatan. Keterlibatan orang tua dalam 
mengembangkan pola perilaku positif dalam pemeliharaan kesehatan diimplementasikan kepada anaknya dalam kehidupan seharihari baik dalam bentuk langsung maupun tidak langsung.

Hasil penelitian menunjukkan ratarata tindakan mencuci tangan anak usia prasekolah setelah diberikan pendidikan kesehatan dengan bernyanyi lagu cuci tangan adalah 16,36 , nilai median 16 , skor minimum 14 dan maksimum 20. Menurut Rasyid (2014) metode bernyanyi merupakan salah satu bentuk metode yang bisa menggontrol dan mengamati setiap dari perkembangan anak, seperti perkembangan verbalnya, pendengarannya daya tangkap, motorik, peniruan dan lain sebagainya. Pendidikan kesehatan metode bernyanyi mempunyai peranan yang sangat penting terhadap perubahan perilaku anak prasekolah. Perubahan yang terjadi karena adanya peningkatan pengetahuan serta penyerapan informasi yang baik terhadap pendidikan kesehatan metode bernyanyi yang telah diberikan.

Anak usia prasekolah dalam penelitian ini setelah diberikan pendidikan kesehatan dengan bernyanyi lagu cuci tangan terjadi peningkatan rata-rata tindakan mencuci tangan, hasil ini sesuai dengan pendapat Lestari (2012) yang mengatakan bahwa metode bernyanyi memberikan cara belajar yang sangat menyenangkan bagi anak karena dilakukan seperti bermain. Selain itu, peragaan cuci tangan yang menyertai metode bernyanyi menyebabkan anak dapat secara langsung mempraktekkan secara tepat intervensi yang telah diberikan, sehingga materi yang disampaikan lebih mudah diterima oleh anak.

Hasil penelitian ini sejalan oleh penelitian sebelumnya yang dilakukan oleh Rahmawati (2014) menunjukkan ada pengaruh pendidikan kesehatan dengan pembelajaran gerak dan lagu terhadap kemampuan mencuci tangan pada anak usia 7-12 tahun di SDN Pace 2 Kecamatan Silo Kabupaten Jember. Penelitian lain oleh Listyowati (2014), menunjukkan bahwa intervensi promosi kesehatan yang dilakukan terbukti dapat meningkatkan pengetahuan, sikap dan praktek siswa kelas 5 SDN Pengasinan IV Kota Bekasi mengenai cuci tangan pakai sabun $(\mathrm{p}=0,000)$. Penelitian yang dilakukan oleh Rindafit (2015) menunjukkan bahwa terdapat efektifitas pendidikan kesehatan terhadap praktik cuci tangan pada anak prasekolah di PAUD Darunnajah Desa Tamansari Kecamatan Wuluhan Kabupaten Jember $(\mathrm{p}=0,000)$.

Peneliti berpendapat, peningkatan rata-rata tindakan mencuci tangan merupakan pengaruh dari pendidikan kesehatan metode bernyanyi. Pendidikan kesehatan dengan metode bernyanyi telah meningkatkan pengetahuan responden sehingga tindakan dalam mencuci tangan berubah menjadi lebih baik. Peningkatan tindakan terjadi karena pendidikan tersebut diterima dengan baik oleh responden. Metode bernyanyi memberikan cara belajar yang sangat menyenangkan bagi anak karena dilakukan seperti bermain. Selain itu, peragaan cuci tangan yang menyertai metode bernyanyi menyebabkan anak dapat secara langsung mempraktekkan secara tepat intervensi yang telah diberikan, sehingga materi yang disampaikan lebih mudah diterima oleh anak.

Berdasarkan hasil uji statistik paired$t$ diperoleh nilai $\mathrm{p}=0,000(\alpha<0,05)$ artinya ada pengaruh pendidikan kesehatan dengan bernyanyi lagu cuci tangan terhadap tindakan mencuci tangan pada anak usia prasekolah di Sekolah Taman Kanak-Kanak Bakti 3 Denpasar. Menurut Wahit (2012) pendidikan kesehatan mempunyai peranan yang penting untuk mengubah perilaku. Cara tepat untuk mengubah perilaku adalah dengan cara pendekatan edukatif, salah satu kegiatan edukatif adalah bernyanyi.

Hasil penelitian ini sesuai dengan pendapat Ismaniar (2010), peningkatan perilaku mencuci tangan merupakan pengaruh dari bernyanyi lagu cuci tangan. Melalui kegiatan menyanyi banyak pesanpesan pendidikan yang bisa disampaikan kepada anak. Dengan demikian maka pengetahuan dan keterampilan perilaku hidup sehat bisa disampaikan kepada anak melalui kegiatan bernyanyi. Melalui kegiatan bernyanyi apalagi kalau dilakukan bersama-sama antara pendidik dan anak maka akan tercipta suasana yang menyenangkan, sehingga pesan disampaikan 
pendidik mudah diserap oleh anak. Jadi metode bernyanyi bisa digunakan dalam mengembangkan perilaku hidup sehat pada anak usia dini.

Menurut Rahmawati (2014) metode bernyanyi adalah salah satu bentuk metode yang bisa menggontrol dan mengamati setiap dari perkembangan anak, seperti perkembangan verbalnya, pendengarannya daya tangkap, motorik, peniruan dan lain sebagainya. Selain itu, nyanyian dapat membuat belajar menjadi lebih menyenangkan dan anak tidak cepat bosan, sehingga informasi akan mudah ditangkap. Menurut Wiflihani (2012) mengatakan bahwa pelatihan, pembiasaan, pembelajaran dan pedidikan pada usia dini akan lebih efektif jika digunakan media bernyanyi. Selain tidak terkesan menggurui, memerintah atau melarang, juga disampaikan dengan suasana riang gembira, mudah diingat dan tidak menyakitkan hati anak.

Pendidikan kesehatan dengan bernyanyi lagu cuci tangan berpengaruh terhadap tindakan mencuci tangan pada anak usia prasekolah, Menurut Lestari (2012) Taman Kanak-kanak memiliki peran penting untuk mengembangkan karakter positif pada anak, pada masa ini perkembangan anak sangat cepat dan akan berpengaruh pada masa yang akan datang sehingga perlu distimulasi agar berkembang secara optimal. Pendidik perlu menggunakan metode yang kreatif dan inovatif. Salah satu metode yang bisa digunakan adalah dengan nyanyian karena nyanyian menjadi bagian dari kehidupan anak selain aktivitas bermain. Metode ini dianggap lebih tepat bagi anakanak karena terkesan gembira dan tidak membosankan.

Hasil penelitian ini didukung oleh penelitian sebelumnya yang dilakukan oleh Jayastri (2014) menunjukkan ada pengaruh bernyanyi lagu cuci tangan terhadapperilaku mencuci tangan padaanak usia prasekolah (5-6 tahun) di PAUD Kumara LokaDenpasar $(\mathrm{p}=0,000)$. Penelitian Vina (2015) menunjukkan ada pengaruh pendidikan kesehatan dengan metode bernyanyi terhadap perilaku mencuci tangan anak prasekolah (3-6 tahun) $(\mathrm{p}=0,000)$.
Peneliti berpendapat, penggunaan metode pembelajaran yang tepat adalah salah satu prinsip dalam pemberian pendidikan kesehatan pada anak usia prasekolah. Metode pembelajaran yang tepat dapat merangsang perhatian, minat, pikiran, dan perasaan siswa dalam proses belajar sehingga dapat memahami materi yang diberikan. Bernyanyi merupakan salah satu metode pembelajaran yang memang dianjurkan untuk anak usia prasekolah. Bernyanyi juga merupakan media yang sangat terjangkau karena dapat dilakukan tanpa menggunakan alat khusus, serta dapat digunakan kapan dan dimana saja, seorang guru dapat menggunakan media lagu untuk menyampaikan informasi kesehatan kepada anak-anak. Guru dapat memodifikasi syair lagu dengan menggunakan irama yang mudah dihafalkan dan diingat sehingga anak dapat lebih mudah menerapkan praktik mencuci tangan.

Hasil penelitian ini sejalan dengan hasil penelitian Apriany (2012) tentang perbedaan perilaku mencuci tangan sebelum dan sesudah diberikan pendidikan kesehatan pada anak usia 4-5 tahundi TK At-Taqwa Cibeber Cimahi. Rerata cuci tangan responden sebelum diberikan pendidikan kesehatan adalah 2,78 dan setelahnya menjadi 9,44. Hasil uji $t$ didapatkan ada perbedaan signifikan perilaku cuci tangan sesudah diberikan pendidikan kesehatan $(p=0,001)$. Penelitian Rahmawati (2014) tentangpengaruh pendidikan kesehatan terhadap perilaku cuci tangan pakai sabun pada anak di Janturan Mlati Sleman Yogyakarta. Hasil penelitian ini sebagian besar perilaku tentang mencuci tanggan pakai sabun sebelum mendapatkan pendidikan kesehatan pada kategori kurangsebanyak 49 siswa $(83,1 \%)$, setelah mendapatkan pendidikan kesehatan mengalami perbedaan yaitu pada kategori baik sebanyak 50 siswa $(84,7 \%)$. Hasil analisis didapatkan ada pengaruh pendidikan kesehatan terhadap perilaku cuci tangan pakai sabun pada anak $(\mathrm{p}=0,000)$.

Menurut Putra (2014) metode demontrasi membuat anak akan lebih mudah mengingat apa yang dilihat, dengan dilakukannya pendidikan kesehatan dengan cara demontrasisangat membantu anak 
untuk bisa mengingat cara mencuci tangan dengan langkah cuci tangan yang baik dan benar, sehingga bisa menjadi kebiasaan pada anak. Kebiasaan untuk menjaga kebersihan terutama kebersihan tangan harus diajarkan mulai anak usia dini.

Peneliti berpendapat, mengajarkan anak mencuci tangan secara langsung melalui demontrasi akan mempengaruhi kemampuan anak karena anak langsung melihat dan mempraktekkan langkahlangkah mencuci tangan sehingga akan mudah diingat. Peneliti saat memberikan demontrasi juga diserta dengan memberi penjelasan tentang manfaat cuci tangan dam dampak yang bisa ditimbulkan akibat tidak memcuci tangan. Anak-Anak sangat penting diberikan pemahaman tentang cuci tangan karena penerimaan perilakubaru perlu didasari olehpengetahuan, pemahaman, kesadaran, dan sikap positif, maka perilaku tersebut akan bersifat langgeng. Sebaliknya apabila perilaku tidak didasari oleh pengetahuan, pemahaman dan kesadaran maka tidak akan berlangsung lama. Sepertianak-anak dihimbau untuk cuci tangan olehtanpa mengetahui makna dantujuan mencuci tangan pakai sabun, makasebagian besar anak akan banyak menyepelekan kegiatan mencuci tangan tersebut walaupun telah mendapatkancontoh carta mencuci tangan.

Hasil penelitian didukung oleh penelitian Kurniasari (2016) tentang perbandingan hand washing promotion dengan metode bernyanyi dan hand washing dance terhadap pengetahuan teknik mencuci tangan anak usia prasekolah, Hasil penelitian didapatkan diketahui bahwa nilai $p=0,000 \quad(\alpha<0,05) \quad$ sehingga terdapat perbedaan yang bermakna antara peningkatan pengetahuan teknik mencuci tangan dengan metode bernyanyi dan handwashing dance. Selain itu, didapatkan data bahwa nilai rata-rata peningkatan skor sebelum dan setelah intervensi hand washing dance lebih tinggi dibandingkan dengan metode bernyanyi yakni 54,71. Maka dapat disimpulkan bahwa intervensi hand washing dance lebih efektif dalam meningkatkan pengetahuan teknik mencuci tangan anak usia prasekolah
Menurut Widhianawati (2011), metode hand washing dance terdapat beberapa stimulasi yang dipengaruhi, yaitu stimulasi gerakan, penglihatan, dan pendengaran. Stimulasi gerakan saat menari dapat dijadikan latihan psikomotorik, selain itu dapat membantu merangsang dan meningkatkan kecerdasan musikal serta kecerdasan kinestetik. Pada anak-anak potensi kecerdasan ini dapat distimulus melalui menari, dan olah raga yang mempergunakan lagu dan instrumen musik, seperti menyanyikan lagu untuk anak atau memperdengarkan musik pada saat bermain.Pemaparan terhadap musik secara lebih awal dapat memperkuat kaitan-kaitan antara sel-sel otak dan bahkan mungkin dapat mengarahkan pada pembentukan jalurjalur ikatan baru di dalam otak yang tengah berkembang. Melalui pembelajaran gerak dan lagu dapat meningkatkan kecerdasan kinestetik untuk menggunakan salah satu kemampuan mental dalam mengkoordinasikan gerakan tubuh. Kemampuan ini dapat dirangsang melalui gerakan tubuh, tarian dan olah raga yang berhubungan dengan koordinasi tubuh, keseimbangan, kekuatan, kelincahan dan koordinasi mata dengan tangan dan kaki.

Teori Widhianawati (2011) didukung oleh teori Mulyani \& Gracinia (2007) yang mengatakan stimulasi berupa penglihatan timbul dalam conus atau basilus melalui neurit menuju ke neuron yang berbentuk sel bipoler kemudian diteruskan hingga akhirnya sampai di otak tengah. Kemudian otak tengah mendatangkan gerakan refleks mata agar mata dapat difokuskan ke arah objek yang penting. Pada stimulus pendengaran akan diteruskan oleh serabut saraf menuju ganglion spiralis korti yang terletak di modiolus (pusat kokhlea). Berbagai proses pun terjadi, hingga akhirnya proses stimulasi ini meningkatkan potensial aksi di bagian otak tengah, sehingga substansi nigra menghasilkan neurotransmitter terutamanya dopamin pada akson dopaminergik. Dopamin berfungsi untuk menghantarkan pesan ke bagian otak terutama bagian korteks penglihatan primer di lobus oksipetalis sehingga terjadi pengolahan informasi. Selain itu, nyanyian, musik dan tarian dapat membuat belajar 
Dewa Gede Juliawan: Pengaruh Pendidikan Kesehatan Dengan Bernyanyi Lagu Cuci Tangan Terhadap Tindakan Mencuci Tangan Anak Prasekolah

menjadi lebih menyenangkan dan anak tidak cepat bosan, sehingga informasi akan mudah ditangkap. Jika dilihat dari Kerucut Pengalaman Edgar Dale, orang akan dapat menangkap 90\% informasi yang diberikan apabila langsung melakukan hal yang sebenarnya (Lestari, 2012).

\section{KESIMPULAN}

Implikasi

Hasil penelitian ini dapat menjadi dasar penentuan strategi penerapan perilaku hidup bersih dan sehat (PHBS) pada agregat anak usia pre sekolah.

\section{Keterbatasan}

Tindakan mencuci tangan anak usia prasekolah tidak hanya dilihat pada saat di sekolah, namun bisa diamati di rumah sehingga diperlukan bantuan para orang tua dalam hal meningkatkan kemampuan mencuci tangan anak di rumah. Pada penelitian ini belum dilakukan pengukuran secara menyeluruh kegiatan mencuci tangan anak melalui self repot dari orang tua.

\section{DAFTAR PUSTAKA}

Anugrah. (2014). Permasalahan Umum Kesehatan Anak Usia Sekolah. Diakses kembali dari http://journal.ui.ac.id/ Pada tanggal 13 Pebruari 2018

Apriany. (2012). Perbedaan Perilaku Mencuci Tangan Sebelum dan Sesudah diberikan Pendidikan Kesehatan Pada Anak Usia 4-5 Tahun. The Soedirman Journal Of Nursing.

Departemen Kesehatan Republik Indonesia. (2016). Panduan Penyelenggaraan Hari Cuci Tangan Pakai SabunSedunia (HCTPS) Kedua. Jakarta : Departemen Kesehatan Republik Indonesia

Fitriasari. (2014). Hubungan Perilaku Mencuci Tangan Menggunakan Sabun Dengan Kejadian Diare Pada Anak UsiaPra Sekolah Di Dusun 10 PandowanBrosot Galur Kulon Progo.E Journal Keperawatan (EKp), 1 (1) 1-8.

Ilmi. (2015) . Pengaruh Pendidikan Kesehatan Dengan Metode Bernyanyi
Terhadap Priaku Mencuci Tangan Anak Prasekolah di TK Perwanida Krangkongan Tegalwangi Umbulsari Jember.

Ismaniar. (2010). Metode-Metode Pengembangan Perilaku Hidup Sehat Anak Usia Dini. Jurnal Ilmiah IlmuPendidikan

Jayastri. (2014). Pengaruh Bernyanyi Lagu Cuci Tangan Terhadap Perilaku Mencuci Tangan Pada Anak Usia Prasekolah (5-6 tahun) di PAUD Kumara Loka Denpasar. Skripsi Program Studi Ilmu Keperawatan Universitas Udayana.

Kurniasari. (2016). Perbandingan Hand Washing Promotion Dengan Metode Bernyanyi dan Hand Washing Dance Terhadap Pengetahuan Mencuci tangan Anak Usia Prasekolah Di PAUD TK Pra Widyalaya Gurukula dan PAUD Negeri Pembina Bangli. Skripsi Program Studi Ilmu Keperawatan Fakultas Kedokteran Universitas Udayana

Kushartanti. (2012). Faktor-Faktor yang Berhubungan dengan Perilaku Mencuci Tangan pada Anak Sekolah Dasar Negeri 03 kerTajaya Padalaran.

Lestari. (2012). Pengaruh Kegiatan Rutin Mencuci Tangan Di Sekolah Dengan Perilaku Mencuci Tangan Anak Prasekolah Usia 4-6 tahun di TK Islam terpadu As-Salam kota Malang.

Listyowati. (2014). Pengaruh Intervensi Promosi Kesehatan Terhadap Pengetahuan, Sikap Dan Praktek Cuci Tangan Pakai Sabun Pada Siswa Kelas 5Di SDN Pengasinan IV Kota Bekasi. Jurnal Keperawatan Community of Publishing in Nursing (COPING) NERS 1 (2) 11-15.

Mukhtar. (2016). Gambaran Pengetahuan Dan Pelaksanaan Cuci TanganPada Siswa Sekolah Dasar di MI Muhammadiyah Argosari Kecamatan Ayah Kabupaten Kebumen. Skripsi Progam Studi S1 Keperawatan STIKES Muhammadiyah Gombong

Mulyadi. (2015). Kemampuan Fisik dan Manajemen Diri. Jakarta: Elex Media Komputindo. 
Dewa Gede Juliawan: Pengaruh Pendidikan Kesehatan Dengan Bernyanyi Lagu Cuci Tangan Terhadap Tindakan Mencuci Tangan Anak Prasekolah

Nisarosalinah. (2017). Hubungan Perilaku Cuci Tangan Dengan Kejadian ISPA pada Anak Usia Sekolah di SD kartika XII Akmil Magelang.

Ponidjan, T. dkk. (2013). Hubungan antara prilaku cuci tangan pakai sabun dengan terjadinya diare pada anak usia sekolah di SD GMIM dua kecamatan tareran. Ejournal Keperawatan (E-Kp). Volume 1 (1): 1-8

Pramono, dkk (2011). Pengembangan permainan multimedia interaktif tentang prilaku hidup bersih dan sehat pada siswa sekolah dasar. Pusat Humaniora, Kebijakan Kesehatan dan Pemberdayaan Masyarakat, Badan Peneliti Dan Pengembangan Kesehatan

Purwanto. (2012). Pengantar Perilaku Manusia Untuk Keperawatan. Jakarta: EGC.

Putra. (2014). Penggunaan Media Lagu "Ayo Cuci Tangan" Dalam Meningkatkan Keterampilan Mencuci Tangan (Penelitian Tindakan Kelas pada Anak Tunagrahita Sedang Kelas D2 di SLB "Sabilulungan" Kabupaten Bandung).

Rahmawati. (2014). Pengaruh Pendidikan Kesehatan Dengan Pembelajaran Gerak Dan Lagu Terhadap Kemampuan Mencuci Tangan Pada Anak Usia 7-12 Tahundi SDN Pace 2 Kecamatan Silo Kabupaten Jember Jurnal Ilmiah IlmuPendidikan, 10(2): 36-41

Ramadhan.(2014). Efektifitas Metode Ceramah Dan Bermain DalamPenyuluhan Kesehatan Gigi Dan Mulut Terhadap Pengetahuan Siswa SDN 064026 Ladang Bambu Medan Tuntungan.Jurnal Ilmiah PANNMED 8 ( 3) Januari - April 2014

Rasyid. (2014). Metode-Metode Pengembangan Perilaku Hidup Sehat Anak Usia Dini. Jurnal Ilmiah Ilmu Pendidikan, 10(2): 36-41.

Rindafit. (2015). Efektifitas Pendidikan Kesehatan Terhadap Praktik Cuci Tangan Pada Anak Prasekolah Di PAUD Darunnajah Tamansari
Wuluhan Jember. Skripsi Program Studi Ilmu Keperawatan Universitas Jember

Vina.(2015). Efektifitas MetodeExpository Teaching Terhadap Perilaku Mencuci Tangan Dengan Menggunakan Sabun. Tesis tidak diterbitkan. Fakultas Psikologi Universitas Katolik Soegijapranata Semarang.

Wahit.(2012). Ilmu Kesehatan Masyarakat Konsep dan Aplikasi.Jakarta: Salemba Medika

Wiflihani. (2012). Musik Sebagai Salah Satu Cara Untuk Meningkatkan Kecerdasan Anak. Jurnal diterbitkan. Fakultas Bahasa dan Seni Universitas Negeri Medan

Wong, D.L. (2014). Pedoman Klinis Keperawatan Pediatrik. Ed 4. Jakarta : Buku Kedokteran EGC.

World Health Organization.2016. A Lively and Healthy Me, (www.wpro.who.int), diakses tanggal 8 Pebruari 2018. 